\title{
STUDI KUALITATIF TENTANG MANFAAT DAN KERUGIAN DALAM PENYUSUNAN LAPORAN KEUANGAN PADA UD MITRA PELITA
}

\author{
Maurenthia J. Mandey ${ }^{1}$, David P. E. Saerang ${ }^{2}$, Rudy J. Pusung ${ }^{3}$ \\ 1,2,3 Fakultas Ekonomi dan Bisnis, Jurusan Akuntansi, Universitas Sam Ratulangi, Jl.Kampus Bahu, Manado, \\ 95115, Indonesia \\ E-mail : initialmj.13@gmail.com
}

\begin{abstract}
The financial statements are fundamental for every company, both large companies and small companies. In Indonesia, according to the Ministry of Cooperatives and Micro Small and Medium Enterprises, up to 2013 the total number of business units is 57,900,787, SME's with the largest business units as much as 57,895,721 (99.99\%) and large enterprises as much as 5.066 (0.01\%). The development of SME's is only seen in the number, while in the financial aspect, SME's still lags behind. This condition is also experienced by UD Mitra Pelita who have not prepared financial statements. The purpose of this study is to know how the financial management of UD Mitra Pelita and their views on the benefits and losses in the preparation of financial statements as well as the factors that the reason the owner of the company has not compiled or not prepare financial statements. The method of analysis used in this research is descriptive method with case study design. The results showed that the financial management of UD Mitra Pelita the same as SME's in general that is not yet prepared financial report. This raises many problems in their business activities. The factors that cause UD Mitra Pelita has not compiled financial statements are not much different from SME's in general. However, these factors are not a barrier for UD Mitra Pelita to implement financial reports that have many benefits for their business activities.
\end{abstract}

Keywords:Financial Reports, Benefits, Losses, Factors.

\section{PENDAHULUAN}

Pada dasarnya perusahaan didirikan dengan tujuan untuk memperoleh keuntungan yang maksimal sehingga dapat mempertahankan dan menjaga kelangsungan usaha itu sendiri. Perekonomian yang semakin berkembang ditandainya dengan pendirian perusahaan yang semakin menjamur khususnya Usaha Mikro Kecil dan Menengah. Di Indonesia menurut Kementrian Koperasi dan Usaha Mikro Kecil dan Menengah, hingga tahun 2013 jumlah unit keseluruhan sebanyak 57.900.787, dengan unit usaha terbanyak yaitu UMKM sebanyak 57.895 .721 (99,99\%) dan Usaha Besar sebanyak 5.066 (0.01\%). Usaha Mikro Kecil Menengah (UMKM) merupakan salah satu penggerak perekonomian bangsa. UMKM diharapkan dapat meningkatan daya saing bangsa, pertumbuhan ekonomi, pengurangan kemiskinan, dan peningkatan standar hidup penduduk Indonesia. UMKM harus dapat bersaing dan mampu menangkap setiap kesempatan yang ada agar tetap dapat berkiprah dalam perekonomian bangsa ini.

Perkembangan jumlah UMKM dari tahun ke tahun semakin bertambah. Namun perkembangan UMKM baru terlihat dari sisi jumlahnya saja. Dalam aspek keuangan, hanya sedikit UMKM yang mengalami perkembangan dalam hal kinerja keuangannya. Hal ini tak lepas dari kesadaran pelaku UMKM terhadap pentingnya pengelolaan keuangan perusahaan. Adapun kegiatan penyusunan laporan keuangan, masih dianggap mewah dan belum sebanding dengan kegunaannya. Akibatnya pelaku UKM tidak mengetahui secara persis berapa pendapatan (kas) yang seharusnya diterima, berapa biaya operasi yang seharusnya dikeluarkan dan berapa yang seharusnya masih tersisa. Kalaupun ada 
perencanaan kegiatan, biasanya tidak tersusun secara tertib sehingga mengalami kesulitan bagaimana cara mengalokasikan dana (kas) yang ada sekarang. Permasalahan itu semakin kompleks seiring dengan semakin besarnya kegiatan usaha UKM.

Oleh karena itu setiap usaha memerlukan media keuangan yaitu laporan keuangan yang digunakan sebagai dasar untuk menilai kinerja keuangan perusahaan serta prestasi yang dicapai perusahaan pada masa lampau, sekarang dan perencanaan di waktu yang akan datang. Laporan keuangan umumnya disajikan untuk memberi informasi mengenai posisi-posisi keuangan, kinerja dan arus kas suatu perusahaan dalam periode tertentu. Informasi tersebut diharapkan dapat bermanfaat bagi sebagian besar kalangan pengguna laporan keuangan dalam rangka membuat keputusan.

Pada tanggal 24 Oktober 2016 Dewan Standar Akuntansi Keuangan (DSAK) IAI telah mengesahkan Standar Akuntansi Keuangan Entitas Mikro, Kecil, dan Menengah (SAK EMKM) dan berlaku efektif pada tanggal 1 Januari 2018 (penerapan dini dianjurkan). Dengan adanya SAK EMKM ini diharapkan dapat membantu sekitar 57,9 juta pelaku UMKM di Indonesia dalam menyusun laporan keuangannya dengan tepat dan mudah dibandingkan dengan sak yang berlaku selama ini.

Laporan keuangan adalah hal yang paling essensial bagi pemilik usaha sebagai dasar untuk mengembangkan usaha mereka dalam hal pengambilan keputusan. Namun dalam praktiknya sebagian besar usaha, khususnya UMKM yang belum melakukan pembukuan atau pencatatan keuangan berdasarkan standar akuntansi keuangan. Hal tersebut timbul karena pemilik perusahaan berasumsi bahwa perusahaan mereka belum terlalu besar kegiatan operasinya.

\section{TINJAUAN PUSTAKA}

\subsection{Akuntansi}

Akuntansi merupakan salah satu bidang ilmu dalam ekonomi, untuk orang awam mungkin mendefinisikan akuntansi itu sebagai suatu kegiatan menghitung uang, dan memanage keuangan saja, definisi itu tidak salah hanya saja dalam akuntansi tidak hanya berkaitan dengan penghitungan uang tapi ada beberapa proses dalam suatu siklus akuntansi.

\subsection{Akuntansi Keuangan}

Akuntansi keuangan adalah proses meringkas data keuangan yang diambil dari catatan akuntansi perusahaan dan menerbitkan dalam bentuk laporan tahunan atau laporan keuangan yang sesuai dengan standar yang berlaku umum untuk kepentingan pihak-pihak luar perusahaan.

\subsection{Laporan Keuangan}

Setelah data transaksi dicatat ke dalam jurnal dan di posting dalam buku besar (ledger), laporan akuntansi disiapkan untuk memberikan informasi yang berguna bagi para pemakai laporan (users), terutama sebagai dasar pertimbangan dalam proses pengambilan keputusan kelak. Laporan akuntansi ini dinamakan laporan keuangan (Hery, 2016: 18).

\subsection{Perusahaan}

Perusahaan adalah sebuah organisasi uang beroperasi dengan tujuan menghasilkan keuntungan, dengan cara menjual produk (barang atau jasa) kepada para pelanggannya. Tujuan operasional dari sebagian besar perusahaan adalah untuk memaksimalkan profit. Ditinjau dari jenis usahanya (produk yang dijual) yaitu perusahaan manufaktur, perusahaan dagang, dan perusahaan jasa. Sedangkan ditinjau dari karakteristik bentuk organisasinya yaitu perusahaan perseorangan, perusahaan persekutuan, dan perusahaan perseroan (Hery, 2015).

\subsection{Usaha Mikro Kecil dan Menengah}

Usaha Mikro, Kecil dan Menengah (UMKM) diatur dalam UU Nomor 20 tahun 2008 tentang Usaha Mikro, Kecil dan Menengah. Berikut kutipan dari isi UU 20/2008. 
1. Usaha Mikro merupakan usaha produktif milik orang perseorangan dan/atau badan usaha perorangan yang memiliki aset maksimal 50 juta dan omset sebesar 300 juta.

2. Usaha Kecil merupakan usaha ekonomi produktif yag berdiri sendiri, yang dilakukan oleh orang perorangan atau badan usaha yang bukan merupakan anak perusahaan atau bukan cabang perusahaan yag dimiliki, dikuasai, atau menjadi bagian baik langsung maupun tidak langsung dari usaha menengah atau usaha besar yang memiliki aset lebih dari 50 juta sampai 500 juta dan omset sebesar 300 juta sampai 2.5 Milyar.

3. Usaha Menengah merupakan usaha ekonomi produktif yang berdiri sendiri, yang dilakukan oleh orang perseorangan atau badan usaha yang bukan merupakan anak perusahaan atau cabang perusahaan yang dimiliki, dikuasai, atau menjadi bagian baik langsung maupun tidak langsung dengan Usaha Kecil atau usaha besar yang memiliki aset lebih dari 300 juta sampai 10 Milyar dan omset sebesar 2.5 Milyar sampai 50 Milyar.

\subsection{Standar Akuntansi Keuangan Entitas Mikro Kecil dan Menengah (EMKM)}

SAK EMKM merupakan Standar digunakan untuk entitas mikro, kecil dan menengah yaitu ETAP (Entitas Tanpa Akuntabilitas Publik) yang memenuhi definisi dan kriteria usaha mikro, kecil, dan menengah sebagaimana diatur dalam peraturan perundang-undangan yang berlaku di Indonesia, selama dua tahun berturut-turut. Standar ini disahkan pada tanggal 1 Januari 2018 (penerapan dini dianjurkan) oleh Ikatan Akuntan Indonesia (IAI). SAK EMKM ini lebih sederhana dibandingkan SAK ETAP, yaitu dalam laporan keuangan lengkap SAK EMKM hanya terdapat tiga laporan keuangan sedangkan SAK ETAP memiliki lima laporan keuangan lengkap. Dengan adanya SAK EMKM ini pelaku UMKM dapat lebih mudah menyusun laporan keuangannya sendiri.

\section{METODE PENELITIAN}

\subsection{Jenis Penelitian}

Jenis penelitian ini termasuk dalam penelitian kualitatif menggunakan metode deskriptif dengan desain studi kasus. Dalam penelitian ini bermaksud untuk dapat memahami masalah yang dihadapi dan bagaimana pandangan objek terhadap masalah tersebut dengan cara mendeskripsikan dalam bentuk kata-kata berdasarkan data yang diperoleh.

\subsection{Tempat dan Waktu Penelitian}

1. Tempat Penelitian

Penelitian mengenai Studi Kualitatif tentang Manfaat dan Kerugian dalam Menyusun Laporan Keuangan dilakukan pada objek penelitian yaitu UD Mitra Pelita yang terletak di Kabupaten Minahasa Selatan tepatnya di desa Poopo Utara Kecamatan Ranoyapo.

2. Waktu Penelitian

Penelitian ini menghabiskan waktu kurang lebih selama satu bulan yang dimulai pada bulan April 2018, yang dalam waktu tersebut peneliti melakukan wawancara dengan pemilik perusahaan sehingga dapat disimpulkan pandangan perusahaan tentang laporan keuangan.

\subsection{Metode Pengumpulan Data}

\subsubsection{Jenis Data}

Dalam penelitian terdapat dua jenis data yaitu data kuantitatif dan data kualitatif. Dalam penelitian ini menggunakan data kualitatif. Data Kualitatif adalah data yang berupa uraian deskriptif dalam bentuk kata-kata, bukan dalam bentuk angka. Data kualitatif diperoleh melalui beberapa teknik pengumpulan data misalnya wawancara, analisis dokumen, diskusi terfokus atau observasi. 
Jenis data yang digunakan dalam penelitian ini adalah jenis data kualitatif yaitu hasil wawancara dengan UD Mitra Pelita,

\subsubsection{Sumber Data}

Berdasarkan sumbernya, data penelitian dikelompokan kedua jenis data yaitu data primer dan data sekunder. Dalam penelitian ini menggunakan data primer.

1. Data primer merupakan data yang didapat dari sumber pertama, baik dari individu atau perseorangan atau data yang diperoleh dari sumber data pertama di lokasi penelitian atau objek penelitian.

Data primer dalam penelitian ini adalah hasil observasi dan wawancara yang diperoleh secara langsung dari objek penelitian

\subsubsection{Teknik Pengumpulan Data}

a) Wawancara

Wawancara dilaksanakan dengan melakukan tanya jawab langsung dengan pihakpihak yang bersangkutan untuk mendapatkan data dan informasi yang rinci serta memahami latar belakang sikap dan pandangan narasumber. Wawancara juga diharapkan untuk mendapat keterangan mengenai penerapan akuntansi, pengelolaan keuangan dan kendala yang dihadapi dalam menyusun laporan keuangan.

b) Observasi

Observasi merupakan salah satu teknik pengumpulan data yang tidak hanya mengukur sikap dari responden namun juga dapat digunakan untuk merekam berbagai fenomena yang terjadi. Teknik ini digunakan bila penelitian ditujukan untuk mempelajari perilaku-perilaku manusia, proses kerja, gejala-gejala alam dan dilakukan pada responden yang tidak terlalu besar. Dalam hal ini peneliti mengobservasi kegiatan-kegiatan yang dilakukan UD Mitra Pelita.

\subsubsection{Metode Analisis}

Dalam penelitian ini, penulis menganalisis data hasil wawancara dengan pemilik UD Mitra Pelita tentang pandangannya terhadap manfaat dan kerugian laporan keuangan dan penyebab usaha ini belum menyusun laporan keuangan.

\section{HASIL PENELITIAN DAN PEMBAHASAN}

\subsection{Sejarah dan Profil Perusahaan}

UD Mitra Pelita sudah berdiri 13 tahun yaitu sejak tahun 2005, terletak di Kompleks Pasar Raya Desa Poopo Utara Kabupaten Minahasa Selatan. UD Mitra Pelita merupakan usaha dagang yang menjual bahan bangunan seperti semen, besi, seng, tehel, dan sebagainya. Pada saat didirikan usaha, UD Mitra Pelita merupakan toko bahan bangunan pertama yang ada di Desa Poopo Raya, sehingga usaha ini berkembang pesat karena memonopoli pasar dalam bidang usaha dagang bahan bangunan. Pada saat itu, toko ini bernama UD Berkat hingga pada tahun 2014 berubah menjadi UD Mitra Pelita. Dahulu UD Mitra Pelita hanya memiliki satu toko saja dan tidak memiliki gudang serta hanya menjual bahan pokok bangunan yaitu semen, seng, besi, dan cat. Pada saat itu, usaha ini hanya dikelola oleh pemilik yaitu bapak Berth beserta istrinya dan tidak memiliki buruh ataupun karyawan. Bapak Berth mendirikan usaha ini awalnya hanya dengan modal dua puluh juta rupiah.

Seiring perkembangannya, sekarang usaha ini memiliki satu toko dan tiga gudang yang dikelola secara langsung oleh pemiliknya yaitu Bapak Berth beserta istrinya dan dua orang buruh serta satu orang sopir. Pendapatan rata-rata yang diperoleh setiap harinya oleh UD Mitra Pelita berkisar 8.000.000 hingga 10.000.000 jika kondisi pasar sunyi pembeli dan berkisar 10.000.000 sampai 20.000.000 jika kondisi pasar ramai pembeli dan terdapat banyak proyek pembangunan. UD Mitra Pelita memiliki aset untuk tanah dan bangunan sebesar 
2.500.000.000, untuk persediaan barang dagang sebesar 1.000.000.000, dan kendaraan bermotor sebesar 400.000.000.

Dalam menjalankan usahanya, UD Mitra Pelita belum menyusun laporan keuangan. Pemilik usaha hanya mencatat harga pokok penjualan, utang dan piutang usaha. Akibatnya pemilik usaha tidak dapat mengetahui dengan pasti keuntungan dan kerugian yang didapatkan. Hal yang membuat UD Mitra Pelita belum menyusun laporan keuangan alasannya sama seperti UMKM lain yaitu bapak Berth sebagai pemilik perusahaan tidak memiliki pengetahuan tentang prosedur penyusunan laporan keuangan.

Di lingkungan UD Mitra Pelita banyak terdapat usaha-usaha dagang lainnya karena lokasi usahanya terletak didepan Pasar Raya Poopo yang merupakan satu-satunya pasar yang ada di kecamatan tersebut. Untuk saat ini belum ada dari usaha-usaha tersebut yang menyusun laporan keuangan. Banyak dari usaha-usaha tersebut telah gulung tikar. Kebanyakan penyebab dari usaha-usaha tersebut gulung tikar adalah pengambilan keputusan investasi yang kurang tepat dan keterbatasan pemilik usaha dalam melakukan pengawasan terhadap persediaan yang ada, yaitu banyak terjadi kecurangan dan manipulasi persediaan yang dilakukan karyawan mereka.

Kesulitan yang sama juga dialami oleh Bapak Berth yaitu dalam investasi baru yang ia jalankan yaitu pembangunan rumah kos yang ada di Manado. Dalam pembangunan tersebut terdapat banyak kendala, salah satunya dalam hal pendanaan. Pada saat itu Bapak Berth mengambil keputusan untuk membangun dikarenakan kas yang dimiliki saat itu dianggapnya bisa untuk melakukan pembangunan, padahal masih banyak utang yang belum dibayarkan dan penjualan yang tidak dapat diprediksi, kadang penjualan bisa turun drastis.

Berdasarkan pengamatan peneliti, hal tersebut disebabkan oleh pengelolaan keuangan yang masih berjalan tradisional dan tidak memiliki laporan keuangan yang menjadi ciri khas Usaha Mikro Kecil dan Menengah (UMKM).

\subsection{Pembahasan}

\section{Perkembangan dan Peluang dalam bidang usaha UD Mitra Pelita}

Bapak Berth mendirikan UD Mitra Pelita dengan modal seadanya, akan tetapi karena memiliki potensi yang besar yaitu belum adanya toko bahan bangunan yang ada di desa Poopo membuat UD Mitra Pelita menguasai pasar yang ada.

Dengan menguasai pasar, perkembangan usaha akan melaju pesat. Dibuktikan hanya dengan rentan waktu satu tahun Bapak Berth dapat membangun tempat yang lebih besar dan persediaan barangnya pun bertambah banyak.

UD Mitra Pelita merupakan perusahaan perseorangan yang dijalankan sendiri oleh Bapak Berth. Karakteristik perusahaan perseorangan yaitu apabila perusahaan memperoleh keuntungan atau kerugian (profit or loss) maka seluruh keuntungan akan dinikmati sendiri dan seluruh kerugian akan ditanggung sendiri oleh si pemilik tunggal serta pemilik bertanggung jawab penuh dengan seluruh kewajiban dan pengambilan keputusan bisnis. Kelebihan perusahaan perseorangan selain pajak penghasilan yang dikenakan hanya pada level individu yaitu pajak atas nama pribadi juga beban gaji yang dikeluarkan tidak banyak, yaitu sesuai dengan kebutuhan karyawan usaha yang dijalankan atau sesuai keinginan pemilik usaha.

Dari perkembangan usaha UD Mitra Pelita dapat dilihat bahwa usaha UMKM dijalankan secara fleksibel, yaitu sesuai dengan keinginan pemilik usaha. Hal tersebut menjadikan UMKM sebagai pilihan bagi setiap orang yang ingin membangun usaha sendiri. Selain itu UMKM dapat betahan dengan kondisi ekonomi krisis, dibuktikan pada krisis ekonomi tahun 1997 yang lalu, dimana banyak usaha berskala besar yang mengalami stagnasi bahkan berhenti aktivitasnya, sektor UMKM terbukti lebih tangguh dalam menghadapi perubahan situasi pasar tersebut. 


\section{Pengelolaan Keuangan UD Mitra Pelita}

Perkembangan usaha UD Mitra Pelita tidak dibarengi dengan pengelolaan keuangan yang baik. Seperti sebagian besar UMKM lain, UD Mitra Pelita belum menyusun laporan keuangan.

Alasan utama UD Mitra Pelita belum menyusun laporan keuangan tidak berbeda dengan alasan UMKM pada umumnya, yaitu tidak memiliki pengetahuan tentang penyusunan laporan keuangan

Solusi untuk dapat menyusun laporan keuangan yaitu UD Mitra Pelita harus merekrut ahli akuntansi untuk membantu dalam menyusun laporan keuangan. Akan tetapi solusi itu sukar untuk dijalankan. Penyebabnya yaitu, sulit menyisihkan waktu untuk mencari ahli akuntansi yang dapat membantu dalam penyusunan laporan keuangan, tidak ingin mengeluarkan biaya serta sulit menaruh kepercayaan untuk mengelola keuangannya.

Banyak perusahaan mikro kecil dan menengah bertanya apakah perlu bagi perusahaan mereka menerapkan laporan keuangan. Menurut UU No. 28 Pasal tahun 2007, wajib pajak orang pribadi yang melakukan kegiatan usaha/ pekerjaan bebas dimana peredaran bruto yang diperoleh kurang dari 4.500.000.000/ tahun tidak wajib menyelenggarakan pembukuan, namun wajib melakukan pencatatan.

Meskipun tidak wajib menerapkan laporan keuangan, UMKM perlu menerapkan laporan keuangan, termasuk UD Mitra Pelita. Akan tetapi, Bapak Berth sebagai pemilik UD Mitra Pelita menganggap bahwa usahanya belum memerlukan laporan keuangan

Bapak Berth memiliki pola pikir yang sama dengan sebagian besar pelaku UMKM, yaitu mereka jarang mengerahkan perhatian kepada hal-hal yang mendetail yaitu angkaangka kecil dan lebih memilih mencurahkan perhatian kepada hal-hal yang lebih besar, khususnya business strategy yaitu menarik pelanggan, memenangkan pasar, mencari supplier murah, investasi baru, dan sebagainya. Pola pikir seperti itu menyebabkan sebagian besar UMKM tidak memiliki keuangan yang stabil.

Sebagian besar pelaku UMKM salah satunya Bapak Berth menjalankan bisnisnya dengan pengalaman dan instinc. Sehingga dalam pengambilan keputusan, asalkan masuk akal dan sesuai dengan naluri mereka bisa mengambil keputusan tersebut.

Hal tersebut buruk dalam kaitannya dengan pengelolaan keuangan. Dalam usaha pasti ada pasang surutnya, yaitu terdapat "high dan low season" yang berpengaruh terhadap tingkat laba/ rugi, ketersediaan kas, dan kondisi kegiatan operasional usaha. Pada tingkat profitabilitas yang tinggi yaitu "high season" dimana penjualan meningkat, resiko yang ditimbulkan akbibat lebih banyak mengandalkan instinc atau naluri, tidak terlalu dirasakan yaitu tidak adanya gangguan operasional dan kas, sehingga pelaku UMKM berpikir kondisi usaha mereka berjalan baik. Sehingga pada saat "low season" dimana penjualan menurun dan menyebabkan tingkat laba menurun, ketersediaan kas menipis dan tersendat, kegiatan operasional usaha mulai terganggu. Pelaku UMKM dapat merasakan adanya gangguan yang terjadi akan tetapi tidak mengetahui dengan persis titik permasalahan keuangannya. Seperti UMKM pada umumnya, pengelolaan keuangan UD Mitra Pelita juga buruk akibat tidak memiliki laporan keuangan sehingga banyak permasalahan yang timbul.

Dengan tidak adanya pengelolaan keuangan yang baik, UD Mitra Pelita mengalami masalah-masalah, yaitu sebagai berikut.

1. Tidak mengetahui posisi keuangan yang ada, kinerja keuangan, dan perubahan modal di masa lalu

2. Sering kesulitan modal usaha,

3. Tidak dapat mengetahui keuntungan dan kerugian yang diperoleh,

4. Pengambilan keputusan investasi yang kurang matang.

Masalah-masalah tersebut akan terus berlangsung jika UD Mitra Pelita tidak menyusun laporan keuangan. Instic dan pengalaman saja tidak dapat menyelesaikan masalah 
dalam pengelolaan keuangan. Diperlukan perhatian pada hal-hal yang lebih mendetail yaitu angka terkecil pun harus diketahui keluar dan masuknya. Untuk menelusuri kas masuk dan keluar pelaku UMKM harus menerapkan laporan keuangan. Untuk mengetahui permasalahan keuangan yang dialami dan dimana persisnya terjadi pelaku UMKM perlu menerapkan Akuntansi Keuangan yang dapat menganalisis informasi keuangan dalam laporan keuangan.

\section{a. Manfaat Laporan Keuangan Bagi UD Mitra Pelita}

Berikut manfaat yang dapat diperoleh dari laporan keuangan untuk mengatasi masalah dan kesulitan yang dialami oleh UD Mitra Pelita.

1. Mengetahui informasi tentang posisi keuangan, kinerja keuangan, perubahan modal pemilik di masa lalu. Sehingga UD Mitra Pelita dapat mengetahui dengan persis asset, persediaan dan modal yang Ia miliki.

2. Mengetahui nilai perubahan kas dan distribusinya. Berdasarkan laporan arus kas, UD Mitra Pelita akan mengetahui berapa nilai kenaikan ataupun penurunan kas dalam 1 periode. Selain dari pada itu UD Mitra Pelita pun dapat mengetahui darimana sajakah sumber kas berasal, akan dikeluarkan ke mana saja pengalokasiannya dan berapakah jumlah penerimaan dan pengeluaran kas, baik yang berasal dari kegiatan operasi, investasi maupun yang berasal dari pendanaan. Sehingga UD Mitra Pelita tidak akan mengalami kesulitan modal yang disebabkan oleh penyaluran modal yang tidak benar karena memiliki pengelolaan kas yang sistematis.

3. Mengetahui keuntungan dan kerugian yang diperoleh setiap periode melalui laporan laba rugi, sehingga UD Mitra Pelita dapat mengetahui hasil kinerja keuangan dan/atau hasil kegiatan operasionalnya.

4. Menjadi salah satu bahan dalam pengambilan keputusan. Data dalam laporan keuangan dapat digunakan untuk pengambilan keputusan di masa yang akan datang. Sehingga dalam pengambilan keputusan investasi UD Mitra Pelita dapat dilakukan dengan matang.

\section{Kerugian Laporan Keuangan bagi UD Mitra Pelita}

Dalam penyusunan laporan keuangan tidak ada kerugian yang akan dialami oleh UD Mitra Pelita. Akan tetapi harus ada pengorbanan waktu dan biaya yang diberikan. Pertama waktu, jika pemilik usaha memiliki pengetahuan tentang akuntansi sehingga tidak perlu merekrut jasa akuntan, ia harus menyediakan waktu untuk menyusun laporan keuangan. Akan tetapi pandangan umum perusahaan kecil, pembukuan dan akuntansi sifatnya administratif belaka dan tidak menghasilkan uang. Bagi perusahaan kecil, waktu mereka akan lebih bermanfaat untuk menjalankan strategi bisnis dan melayani pelanggan. Kedua biaya, jika pemilik perusahaan tidak memiliki pengetahuan tentang pembukuan dan akuntansi harus merekrut jasa akuntan dan itu menimbulkan beban bagi perusahaan. UD Mitra Pelita enggan untuk mengeluarkan biaya untuk hal yang mereka pikir tidak menghasilkan uang bagi usaha mereka.

a. Faktor-Faktor yang menyebabkan UD Mitra Pelita Belum menyusun Laporan Keuangan

Meskipun menyadari manfaat yang diberikan melalui penyusunan laporan keuangan, tidak membuat UD Mitra Pelita untuk memutuskan menyusun laporan keuangan. Hal tersebut disebabkan oleh faktor-faktor sebagai berikut.

1. Sumber Daya Manusia (SDM) dalam Keuangan

2. Tingkat Kompetensi

3. Waktu

4. Biaya

Faktor-faktor tersebut umumnya dialami oleh sebagian besar pelaku UMKM bukan hanya UD Mitra Pelita. Akan tetapi, faktor-faktor tersebut tidak menjadi penghalang bagi 
mereka untuk dapat menerapkan laporan keuangan bagi usahanya. Kesadaran akan pentingnya laporan keuangan untuk pelaku UMKM diharapkan semakin ditingkatkan lagi.

\section{KESIMPULAN DAN SARAN}

\subsection{Kesimpulan}

Berdasarkan hasil analisis pandangan UD Mitra Pelita melalui hasil wawancara yang diperoleh, maka dapat disimpulkan:

1. UD Mitra Pelita belum menyusun laporan keuangan. Faktor- faktor yang membuat UD Mitra Pelita belum menyusun laporan keuangan adalah banyak kendala-kendala yang dihadapi oleh UD Mitra Pelita untuk menyusun laporan keuangan, diantaranya adalah tidak ada sumber daya manusia yang memadai, tingkat kompetensi dalam bidang keuangan pemilik UD Mitra Pelita rendah, serta pemilik usaha enggan untuk memberikan pengorbanan waktu dan biaya dalam menyusun laporan keuangan.

2. Setelah di jelaskan tentang manfaat yang akan diperoleh jika menyusun laporan keuangan, Bapak Berth selaku pemilik UD Mitra Pelita menyadari pentingnya laporan keuangan bagi usahanya. Akan tetapi karena kendala-kendala yang dihadapi, UD Mitra Pelita belum memikirkan untuk menyusun laporan keuangan dan menganggap usahanya belum memerlukan laporan keuangan. Faktor utama UD Mitra Pelita belum menyusun laporan keuangan sama seperti UMKM pada umumnya yaitu tidak ada kompetensi atau pengetahuan yang memadai tentang pengelolaan laporan keuangan.

3. Dalam penyusunan laporan keuangan, tidak ada kerugian yang akan dialami, namun harus ada pengorbanan dalam hal waktu dan biaya. Perusahaan kecil seperti UD Mitra Pelita enggan untuk mengorbankan waktu dan biaya untuk hal yang tidak menghasilkan uang karena menganggap laporan keuangan hanya bersifat administratif.

\subsection{Saran}

Dari hasil penelitian dan pembahasan yang dilakukan, maka saran dari penulis yaitu sebagai berikut.

1. Bagi UD Mitra Pelita

UD Mitra Pelita diharapkan mengubah pola pikir terhadap laporan keuangan dan lebih peduli dengan tata kelola keuangan melalui penyusunan laporan keuangan. Meskipun dalam menyusun laporan keuangan harus mengorbankan biaya dan waktu akan tetapi laporan keuangan sangat membantu usaha untuk dapat mengetahui dengan persis posisi keuangan yang dimiliki dan dapat menjaga usaha berjalan stabil serta jauh dari resiko kebangkrutan sehingga akan terjadinya perkembangan dalam kondisi keuangan usaha dan keberlangsungan usaha yang baik serta banyak manfaat lain juga yang akan diperoleh secara langsung maupun tidak langsung.

2. Bagi pemerintah

Pemerintah diharapkan mengadakan seminar-seminar tentang pentingnya laporan keuangan untuk pelaku UMKM sehingga dapat mengubah pola pikir mereka dan meningkatkan kesadaran akan pentingnya laporan keuangan. Dengan jumlah UMKM yang lebih besar dari Usaha Besar merupakan harapan dalam penggerak perekonomian bangsa, sehingga pemerintah diharapkan lebih memperhatikan UMKM.

3. Bagi Fakultas Ekonomi dan Bisnis Jurusan Akuntansi

Bagi Fakultas Ekonomi dan Bisnis Jurusan Akuntansi diharapkan dapat membuat program praktek penyusunan laporan keuangan bagi UMKM, agar mahasiswa akuntansi dapat lebih terlatih dalam menyusun laporan keuangan serta dapat mengenalkan laporan keuangan pada pelaku UMKM sehingga dapat membantu mereka mengelola keuangan dengan benar. 


\section{DAFTAR PUSTAKA}

Anastasia, Diana dan Lilis, Setiawati, 2017. Akuntansi Keuangan MenengahBerdasarkan Standar Akuntansi Keuangan Terbaru. Yogyakarta: ANDI.

Badriyah, Hurriyah. 2015. Praktis Menyusun Laporan Keuangan. Depok: Vicosta Publishing.

Deanta. 2016. Memahami pos-pos dan angka-angka dalam laporan keuangan untuk orang awam. Yogyakarta: Gava Media.

Duska, Ronald F and Brenda Shay Duska. 2011. Accounting Ethics. United Kingdom: Blackwell Publishing. E-Book.

Endraswara, Suwardi. 2012. Metodologi Penelitian Kebudayaan. Yogyakarta: Gadjah Mada University Press.

Fees, Warren, Reeve. 2006. Pengantar Akuntansi. Jakarta: Salemba Empat.

Frasawi, Jusuf Habel. 2016. "Analisis Pelaporan Keuangan Berdasarkan SAK ETAP pada Koperasi Unit Desa (KUD) Sejahtera Di Kota Sorong. Jurnal EMBA, Vol. 2 No.3.

Hery. 2016. Mengenal dan memahami Dasar-Dasar Laporan Keuangan. Jakarta:

Grasindo.

Hery. 2016. Akuntansi Perusahaan Dagang dan Manufaktur. Jakarta: Grasindo.

Hery. 2015. Pengantar Akuntansi. Comperhensive Edition. Jakarta: Grasindo.

Ismadewi, Ni Komang. 2017. Penyusunan Laporan Keuangan sesuai dengan SAK EMKM pada Usaha Ternak Ayam Boiler (Studi Kasus pada Usaha I Wayan Suadiarsa Desa Panjahan Kecamatan Pupuan Kabupaten Tabanan). Jurnal: Universitas Pendidikan Ganesha Singaraja.

James C, Van Horne dan John M, Wachowicz, 2005. Prinsip-prinsip Manajemen Keuangan. Edisi kedua belas. Jakarta: Salemba Empat.

Martani, Dwi. 2015. Standar Akuntansi Keuangan Entitas Mikro Kecil dan Menengah (SAK EMKM).

Tersedia pada: https://staff.blog.ui.ac.id/martani/2017/08/23/laporan-keuangan-psak-saketap-dan-sak-emkm/.

Nih Lu Gede, Ariantini. 2014. Penerapan SAK ETAP dalam Penyusunan Laporan Keuangan pada Koperasi Simpan Pinjam Lembing Sejahtera Mandiri. Jurnal: Universitas Pendidikan Ganesha Singaraja.

Pambundi, Erik Dwi. 2013. Penerapan Standar Akuntansi Keuangan Entitas Tanpa Akuntabilitas Publik (SAK ETAP) Pada Laporan Keuangan Usaha Mikro, Kecil dan Menengah (Studi pada Usaha Sari Apel, KotaBatu). Jurnal: Universitas Brawijaya.

Ponomban, C Yohanes. 2016. “Analisis Penerapan Laporan Keuangan berdasarkan SAK ETAP pada CV. Bahu Bahtera Indah Manado" Jurnal EMBA.

Pontoh, Winston. 2013. Akuntansi Konsep dan Aplikasi. Jakarta Barat: Halaman Moeka.

Priyati, Novi. 2013. Pengantar Akuntansi. Jakarta: PT. Indeks.

Pura, Rahman. 2013. I Pengantar Akuntansi I Pendekatan Siklus Akuntansi. Jakarta: Erlangga.

Putra, Indra Mahardika. 2017. Pengantar Akuntansi. Yogyakarta: Quadrant.

Putra, Hermon Adhy. Kurniawati, Elisabeth Penti. 2012. Penyusunan Laporan keuangan untuk Usaha Kecil dan Menengah (UKM) Berbasis Standar Akuntansi Keuangan Entitas Tanpa Akuntabilitas Publik (SAK ETAP). Jurnal: Universitas Kristen Satya Wacana.

Rahardjo, Mudja. 2017. Studi Kasus dalam Penelitian Kualitatif: Konsep dan Prosedurnya. Jurnal: Universitas Islam Negeri Maulana Malik Ibrahim Malang.

Rudianto, 2009. Pengantar Akuntansi. Jakarta: Erlangga. 
Stake, Robert E. 1994. "Case Studies" in Norman K. Denzin and Yvonna S. Lincoln (eds.). "Handbook of Qualitative Research", Thousand Oaks, California: SAGE Publications, Inc.

Widi, Restu Kartiko. 2010. “Asas Metodologi Penelitian”. Yogyakarta: Graha Ilmu.

Yin, Robert K. 1994. Case Study Research. Thousand Oaks, London: SAGE Publications, Inc. 